\title{
PENGELOLAAN KEUANGAN DESA DAN SISTEM AKUNTANSI KEUANGAN DESA DALAM RANGKA MENINGKATKAN KINERJA PEMERINTAH DESA PACUNG
}

\author{
Nyoman Sunarti, Ni Nyoman Yunita Lestari, Putu Purnama Yanti, Luh Gede \\ Widya Asty D, Uzlifah, Ni Komang Leli Mayuni \\ Jurusan Akuntansi, Universitas Pendidikan Ganesha, Singaraja, Bali, Indonesia
}

\begin{abstract}
Abstrak
Penelitian ini bertujuan untuk mengungkap pengelolaan keuangan Pemerintah Desa Pacung, mengungkap sistem akuntansi yang diterapkan pada Pemerintah Desa Pacung serta mengungkap pengeloaan keuangan dan sistem akuntansi yang diterapkan pada Pemerintah Desa Pacung dapat meningkatkan kinerja. Pengumpulan data dilakukan dengan teknik wawancara dan observasi. Hasil penelitian menunjukkan bahwa Pengelolaan keuangan desa yang baik dapat meningkatkan kinerja organisasi pemerintah desa dan sistem akuntansi keuangan desa yang baik dapat meningkatkan kinerja organisasi pemerintah di Desa Pacung.
\end{abstract}

Kata kunci: pengelolaan keuangan desa; sistem akuntansi; kinerja pemerintah desa

\begin{abstract}
This study aims to reveal the financial management of the Pacung Village Government, reveal the accounting system applied to the Pacung Village Government and reveal the financial management and accounting system applied to the Pacung Village Government to improve performance. Data collection is done by interview and observation techniques. The results showed that good village financial management can improve the performance of village government organizations and a good village financial accounting system can improve the performance of government organizations in Pacung Village.
\end{abstract}

Keywords: village financial management; accounting system; village government performance

\section{Pendahuluan}

Pemerintah desa dituntut untuk meningkatkan kinerja secara optimal serta mampu menciptakan tujuan masyarakat desa yang sejahtera sebagai suatu implikasi dari penerapan otonomi desa yang mengedepankan akuntanbilitas kinerja dan peningkatan pelayanan publik. Kinerja menjadi gambaran mengenai tingkat pencapaian pelaksanaan suatu kegiatan dalam mewujudkan sasaran, tujuan, visi dan misi organisasi yang tertuang dalam strategi perencanaan suatu organisasi. Keberhasilan suatu organisasi dalam meningkatkan kinerjanya tidak dapat diukur semata-mata hanya dari perspektif keuangannya saja, namun juga harus diukur dari kinerjanya. Dalam peningkatan kinerja organisasi pemerintah desa banyak hal yang bisa digunakan sebagai tolak ukur pembangunan di desa, apakah sudah mensejahterahkan masyarakatnya atau tidak.

Pengelolaan keuangan desa yang berorientasi pada kinerja menunjukan adanya akuntabilitas kinerja yang terdapat keterkaitan antara sasaran strategis yang ingin dicapai dengan jumlah dana yang dialokasikan maka dapat diasumsikan bahwa pengelolaan keuangan desa yang baik mempunyai pengaruh terhadap kinerja suatu instansi atau organisasi. Pengelolaan Keuangan yang baik akan menciptakan laporan keuangan yang baik pula, hal ini dapat mengindikasikan kinerja yang baik pada suatu organisasi. Sistem akuntansi yang memadai memudahkan untuk memverifikasi transaksi-transaksi yang terjadi serta arah aliran dana apakah sudah sesuai dengan tujuan pengalokasian dana tersebut atau belum.

Salah satu pengelolaan kinerja pemerintah desa yaitu di Desa Pacung. Desa Pacung merupakan salah satu desa yang berada di Kecamatan Tejakula Kabupaten Buleleng. Desa Pacung merupakan desa dengan luas wilayah yaitu $1.332 \mathrm{ha} / \mathrm{m} 2$. Pertumbuhan penduduk di Desa Pacung pada tahun 2014 yaitu 4.183 orang dan pada tahun 2015 yaitu 5.441 orang. 
Mata pencaharian masyarakat Desa Pacung sangat beragam, yaitu pertanian, perkebunan dan kerajianan.

Berdasarkan latar belakang ini penulis tertarik untuk melakukan penelitian mengenai sejauh mana pengelolaan keuangan desa dan sistem Akuntansi Keuangan desa terhadap kinerja pemerintah desa. Oleh karena itu maka penulis tertarik untuk melakukan penelitian dengan judul: "Pengelolaan Keuangan Desa dan Sistem Akuntansi Keuangan Desa terhadap Kinerja Pemerintahan Desa Pacung".

Dari permasalahan yang dipaparkan, dapat dirumuskan beberapa rumusan masalah yaitu bagaimana pengelolaan keuangan Pemerintah Desa Pacung, bagaimana sistem akuntansi yang diterapkan pada Pemerintah Desa Pacung serta bagaimana pengeloaan keuangan dan sistem akuntansi yang diterapkan pada Pemerintah Desa Pacung dapat meningkatkan kinerja?

\section{Hasil dan Pembahasan}

\subsection{Pengelolaan Keuangan Pemerinah Desa Pacung}

Pengeloalaan keuangan desa adalah keseluruhan kegiatan yang meliputi perencanaan, pelaksanaan, penatausahaan, laporan, dan pertanggungjawaban keuangan desa. Penyelenggaraan keuangan desa berdasarkan hak asal-usul dan kewenangan lokal berskala desa didanai oleh APBDes. Penyelanggaraan kewenangan, juga dapat didanai oleh anggaran pendapatan, belanja Negara, anggaran pendapatan, dan belanja daerah.

Menurut Pasal 71 ayat (1) UU No 6 tahun 2014 menyatakan bahwa keuangan desa adalah hak dan kewajiban desa yang dapat dinilai dengan uang dan segala sesuatu yang berupa uang dan barang yang berhubungan dengan pelaksanaan hak dan kewajiban desa. Selanjutnya pada ayat (2) dinyatakan bahwa adanya hak dan kewajiban akan menimbulkan pendapatan, belanja, pembiayaan dan pengelolaan keuangan desa.

Dengan diberlakukan peraturan pemerintah no 43 tahun 2014 tentang peraturan pelaksanaan UU No 6 tahun 2014 tentang desa, maka kita coba untuk menjabarkan apa yang sebelum nya di atur pada UU No 6 tahun 2014 diantaranya:

1. Pasal 93 ayat (1) menyatakan bahwa pengelolaan keuangan desa meliputi perencanaan, pelaksanaan, penatausahaan, pelaporan, dan pertanggungjawaban. Berdasarkan pasal 105 dinyatakan ketentuan mengenai pengelolaan keuangan desa yang diatur dalam peraturan mentri (mentri dalam negri).

2. Pasal 94 menyatakan bahwa pengelolaan keuangan desa dilaksanakan dalam masa 1 tahunanggaran terhitung dimulai dari tanggal 1 Januari sampai dengan 31 Desember.

3. Pasal 103 menyatakan bahwa Kepala Desa menyampaikan laporan realisasi pelaksanaan APBDes kepada bupati atau wali kota selama semester tahun berjalan. Laporan semester pertama disampaikan akhir bulan Juli tahun berjalan. Sedangkan laporan semester ke dua disampaikan paling lambat pada akhir Januari tahun berikutnya.

4. Pasal 104 menyatakan bahwa selain penyampaian laporan realisasi pelaksanaan APBDes, Kepala Desa juga menyampaikan pelaporanpertanggungjawaban realisasi pelaksanaan APBDes kepada Bupati/Wali Kota setiap tahun anggaran. Laporan tersebut merupakan bagian yang tidak terpisahkan dari laporan penyelanggaraan pemerintah desa kepada bupati/wali kota melalui Camat/sebutan lain setiap akhir tahun anggaran.

Sebagaimana telah dinyatakan sebelumnya pengelolaan keuangan desa meliputi; perencanaan, pelaksanaan, penatausahaan, pelaporan, dan pertanggungjawaban yang dapat dijelaskan sebagai berikut:

1. Perencanaan

a. Rancangan peraturan desa tentang APBDes dibut, disampaikan oleh Kepala Desa dan dibahas dengan Badan Permusyawaratan Desa untuk disepakati bersama paling lambat bulan Oktober tahun berjalan.

b. Rancangan peraturan desa tentang APBDes yang telah disepakati disampaikan oleh Kepala Desa kepada Bupati/ Wali kota melalui Camat/sebutan lain paling lambat tiga hari sejak disepakati untuk di evaluasi. 
c. Bupati/Wali kota melakukan evaluasi paling lama 20 hari sejak diterimanya rancangan peraturan desa tentang APBDes dalam hal ini Bupati/Wali kota tidak melakukan evaluasi dalam batas waktu tersebut, maka peraturan desa berlaku dengan sendirinya.

d. Dalam hal ini adanya koreksi yang disampaikan atau penyesuaian yang harus dilakukan dari hasil evaluasi tersebut, maka kepala desa harus melakukan penyempurnaan paling lama 7 hari kerja sejak diterimanya hasil evaluasi.

e. Apabila hasil evaluasi tidak ditindak lanjuti oleh kepala desa dan kepala desa tetap menetapkan Rancangan Peraturan Kepala Desa tentang APBDes menjadi peraturan desa, Bupati/Wali Kota membatalkan peraturan desa denagn keputusan Bupati/Wali Kota. Dengan dilakukan pembatalan peraturan desa tersebut sekaligus menyatakan berlakunya pagu APBDes tahun anggaran sebelumnya. Dalam hal terjadi pembatalan, kepala desa hanya melakukan pengeluaran terhadap penyelanggaraan Pemerintah Desa.

f. Kepala desa memberhentikan pelaksanaan Peraturan Desa paling lambat 7 hari kerja setelah pembatalan dan selanjutnya bersama BPD mencabut peraturan desa yang dimaksud.

g. Dalam hal Bupati/ Wali Kotamendelegasikan evaluasi rancanagan peraturan desa tentang APBDes kepada Camat atau sebutan lain, maka langkah yang dilakukan:

1) Camat menetapkan hasil evaluasi rancangan APBDes paling lama 20 hari kerja sejak diterimanya rancangan peraturan desa tentang APBDes.

2) Dalam hal Camat tidak memberikan hasil evaluasi dalam batas waktu yang ditetapkan, peraturan desa tersebut berlaku dengan sendirinya.

3) Dalam hal ini ada koreksi yang disampaikan atau penyesuaian yang dilakukan dari hasil evaluasi tersebut, kepala desa melakukan penyempurnaan apling alma 7 hari kerja terhitung sejak diterimanya hasil evaluasi.

4) Apabila hasil evaluasi tidak ditindak lanjuti oleh kepala desa dan kepala desa tetap menetapkan rancangan peraturan kepala desa tentang APBDes menjadi peraturan desa, Camat menyampaikan usulan pembatalan peraturan desa kepada Bupati/Wali Kota.

\section{Pelaksanaan}

a. Semua penerimaan pengeluaran dan penerimaan desa dalam pelaksanaan kewenangan desa dilaksanakan melalui rekening kas desa.

b. Semua penerimaan dan pengeluaran desa harus didukung oleh bukti yang lengkap dan sah.

c. Pemerintah desa dilarang melakukan pungutan sebagai penerimaan desa selain yang ditetapkan dalam peraturan desa.

d. Bendahara dapat menyimpan uang dalam kas desa pada jumlah tertentu dalam rangka memenuhi kebutuhan operasional pemerintah desa.

e. Pengeluaran desa yang mengakibatkan beban APBDes tidak dapat dilakukan sebelum rancangan peraturan desa tentang APBDes ditetapkan menjadi peraturan desa.

f. Pengeluaran desa untuk belanja pegawai yang bersifat mengikat dan operasional perkantoran yang ditetapkan dalam peraturan kepala desa tetap dapat dikeluarkan walaupun rancangan peraturan desa tentang APBDes belum di tetapkan.

g. Pelaksana kegiatan mengajukan pendanaan untuk melaksanakan kegiatan harus disertai dengan dokumen diantaranya Rancangan Anggaran Biaya (RAB). Sebelum digunakan, RAB tersebut diverifikasi oleh sekretaris desa dan disahkan oleh kepala desa.

h. Pelaksana kegiatan bertanggung jawab kepada tindakan yang menyebabkan pengeluaran atas beban anggaran belanja kegiatan dengan mempergunakan Buku Pembantu Kas Kegiatan sebagai pertanggungjawaban pelaksanaan kegiatan desa.

3. Penatausahaan

Bendahara desa wajib:

a. Melakukan pencatatan setiap penerimaan dan pengeluaran serta melakukan tutup buku setiap akhir bulan secara tertib. Penata usahaan penerimaan dan pengeluaran 
dilakukan menggunakan: Buku Kas Umum, Buku Kas Pembantu Pajak, Dan Buku Bank.

b. Mempertanggungjawabkan uang melalui laporan pertanggungjawaban.

4. Pelaporan

Kepala desa menyampaikan laporan realisasi pelaksanaan APBDes kepada Bupati/Wali Kota yang meliputi:

a. Laporan semester pertama, berupa Laporan Realisasi pelaksanaan APBDes semester pertama.

b. Laporan semester akhir tahun, berupa laporan realisasi pelaksanaan APBDes semester akhir.

5. Pertanggungjawaban

Kepala desa menyampaikan kepada Bupati/Walikota setiap akhir tahun anggaran laporan yang meliputi :

a. Laporan pertanggung jawaban Realisasi Pelaksanaan APBDesa Tahun Anggaran berkenaan.

1) Merupakan bagian tidak terpisahkan dari laporan penyelenggaraan Pemerintah Desa.

2) Diinformasikan kepada masyarakat secara tertulis dan dengan media informasi yang mudah diakses oleh masyarakat.

3) Disampaikan kepada Bupati/Walikota melalui camat atau sebutan lain.

b. Laporan Kekayaan Milik Desa per 31 Desember Tahun Anggaran berkenaan.

c. Laporan Program Pemerintah dan Pemerintah Daerah yang masuk ke desa.

6. Pembinaan dan Pengawasan

a. Pemerintah Provinsi wajib membina dan mengawasi penerimaan dan penyaluran Dana Desa, alokasi Dana Desa, dan Bagi Hasil Pajak dan Retribusi Daerah dari Kabupaten/Kota kepada Desa.

b. Pemerintah Kabupaten/Kota wajib membina dan mengawasi pelaksanaan pengelolaan keuangan desa.

Pengelolaan Keuangan Desa yang tidak kalah penting dan utama adalah adanya Anggaran Pendapatan dan Belanja Desa (APBDesa). APBDesa pada dasarnya adalah rencana keuangan tahunan Pemerintah Desa. APBDesa terdiri atas:

1) Pendapatan Desa

Meliputi semua penerimaan uang melalui rekening desa yang merupakan hak desa dalam 1 (satu) tahun anggaran yang tidak perlu dibayar kembali oleh desa. Pendapatan Desa diklasifikasikan menurut kelompok dan jenis.

2) Belanja Desa

Meliputi semua pengeluaran dari rekening desa dalam 1 (satu) tahun anggaran yang tidak akan diperoleh pembayarannya kembali oleh desa. Belanja desa dipergunakan dalam rangka mendanai penyelenggaraan kewenangan desa dan diklasifikasikan menurut kelompok, kegiatan dan jenis.

3) Pembiayaan Desa

Meliputi semua penerimaan yang perlu dibayar kembali dan/atau pengeluaran yang akan diterima kembali, baik pada tahun yang bersangkutan maupun pada tahuntahun anggaran berikutnya. Pembiayaan yang diklasifikasikan menurut kelompok dan jenis.

Berdasarkan hasil penelitian melalui wawancara dan data lainnya dalam pelaksanaan keuangan desa Pacung, seluruh penerimaan dan pengeluaran desa dilaksanakan melalui Rekening Kas Desa. Pencairan dana dalam Rekening Kas Desa ditandatangani oleh Kepala Desa dan Bendahara Desa. Semua penerimaan dna pengeluaran desa didukung oleh bukti yang lengkap dan sah serta ditandatangani oleh Kepala Desa dan Bendahara Desa. Belanja Desadiprioritaskan untuk memenuhi kebutuhan pembangunan yang disepakati dalam Musyawarah Desa dan sesuai dengan prioritas pemerinntah baik pemerintah pusat maupun pemerintah provinsi atau kabupaten/kota. Hal tersebut seluruhnya tertuang dalam RKP Desa yang pelaksanaannya akan diwujudkan melalui APBDesa. Setelah APBDesa ditetapkan dalam bentuk Peraturan Desa, Program dan Kegiatan sebagaimana yang telah 
direncanakan baru dapat dilaksanakan sesuai dengan kewenangan yang dimilki oleh desa berdasarkan ketentuan yang berlaku.

Berdsarkan RAB Kegiatan yang telah disetujui oleh Kepala Desa, pelaksanaan kegiatan melakukan proses kegiatan sesuai dengan RAB tersebut misalnya berupa pengadaan barang/jasa yang dilakukan melalui swakelola dan/atau melalui penyediaan barang/desa. Pengadaan barang dan/atau jasa di desa diatur lebih lanjut dengan peraturan Bupati/Walikota dengan berpedoman pada ketentuan peraaturan perundang-undangan. Setelah proses persetujuan/pengesahan belanja dilakukan oleh kepala desa melalui dokumen SPP maka sebagai langkah selanjutnya pelaksanaan kegiatan membuat laporan kegiatan ini dilakukan terhadap kegiatan-kegitan yang telah selesai dilaksanakan yang menggambarkan realisasi fisik dan keuangan serta output yang ada.

Laporan ini dibuat ketika kegiatan telah selesai dilaksanakan sebagai media pemberitahuan tambahan aset (jika ada). Dalam laporan kegiatan diuraikan hasil/keluaran kegiatan beserta biaya yang telah dikeluarkan. Jika keluaran berupa aset yang merupakan bagian kekayaan milik desa maka harus dicatat dalam buku inventaris desa dan dilaporkan dalam Laporan Kekayaan Milik Desa.

Bendahara Desa wajib melakukan pencatatan terhadap seluruh transaksi yang ada berupa penerimaan dan pengeluaran. Bendahara Desa melakukan pencatatan secara sistematis dan kronologis atas transaksi-transaksi keuangan yang terjadi. Penatausahaan keuangan desa yang dilakukan oleh bendahara desa dilakukan dengan cara sederhana, yaitu berupa pembukuan belum menggunakan jurnal akuntansi.

Penerimaan yang bersifat tunai yang diterima oleh Bendahara Desa dibuatkan bukti kuitansi tanda terima dan dicatat oleh Bendahara Desa pada Buku Kas Umum. Sedangkan untuk penerimaan yang bersifat transfer, Bendahara Desa akan mendapat informasi dari bank berupa Nota Kredit atas ddana-dana yang masuk ke dalam Rekening Kas Desa. Berdasarkan nota kredit ini selanjutnya Bendahara Desa melakukan pencatatan ke dalam buku bank. Pencatatan penerimaan baik kas maupun transfer harus disertai dengan bukti yang lengkap dan sah serta dicatat secara benar dan tertib.

Sesuai pasal 35 Permendagri 113 Tahun 2014, Bendahara Desa wajib mempertanggungjawabkan uang melalui laporan pertanggungjawaban. Laporan Pertanggungjawaban ini disampaikan setiap bulan kepada Kepala Desa paling lambat tanggal 10 bulan berikutnya. Sebelumnya, Bendahara Desa melakuakn tutup buku setiap akhir bulan secara tertib, meliputi Buku Kas Umum, Buku Bank, Buku Pajak dan Buku Rincian Pendapatan. Penutupan buku ini dilakukan bersama dengan Kepala Desa.

\subsection{Sistem Akuntansi yang Diterapkan pada Desa Pacung}

Desa seharusnya berkewajiban menyelenggarakan akuntansi untuk mendukung proses akuntabilitas pengelolaan keuangannya kepada publik. Standar akuntansi yang cocok untuk akuntansi desa adalah Standar Akuntansi Pemerintahan (SAP). Setidaknya ada dua alasan yang memperkuat pendapat ini. Pertama, desa bertanggung jawab mengurus urusan pemerintahan (UU 6/2014, Pasal 1) dan kepala desa wajib menyampaikan laporan penyelenggaraan pemerintah desa kepada bupati/walikota (UU6/2014, Pasal 27). Alasan kedua, desa memperoleh pendapat yang diantaranya bersumber dari APBN dan APBD (UU 6/2014, Pasal 72). Dua alasan tersebut menunjukkan hubungan yang erat antara aktivitas desa dengan aktivitas pemerintahan. Mengingat desa memiliki karakteristik yang khas makadimungkinkan adanya suatu sistem akuntansi yang berbeda dengan sistem akuntansi pemerinah pusat atau daerah.

a. Langkah Awal

Peraturan Menteri Dalam Negeri No. 113/2014 tentang Pedoman Pengelolaan Keuangan Desa merupakan dasar bagi pembangunan sistem akuntansi desa. Teknik akuntansi yang dipilih dalam peraturan tersebut relatif masih sederhana. Basis akuntansi yang digunakan adalah basis kas dimana transaksi ekonomi entitas desa diakui dan dicatat pada saat kas diterima atau dibayarkan. Meski berbasis kas, entitas desa tetap diminta menyajikan informasi terkait aset non-kas dan kewajiban pada akhir tahun anggaran. Pembukuan desa dilakukan dengan sistem single entry. Sarana pencatatan 
utama adalah buku kas umum yang berfungsi untuk merekam semua transaksi penerimaan dan pengeluaran berdasarkan jenis kegiatan dibuat buku kas pembantu kegiatan. Selain itu juga ada buku kas pembantu pajak, dan buku bank desa.

Laporan keuangan yang digunakan sebagai pertanggungjawaban kepala desa kepada bupati/walikota adalah Laporan Pertanggungjawaban Realisasi Pelaksanaan APBDesa. Laporan tersebut berisi informasi pendapatan, belanja dan pembiayaan desa. Laporan pertanggungjawaban juga dilampiri dengan Laporan Kekayaan Milik Desa yang isinya mirip dengan neraca, yaitu berupa informasi tentang aset lancar dan tidak lancar, kewajiban jangka pendek, dan kekayaan bersih yang diperoleh dari selisih antara aset dengan kewajiban.

b. Akun-Akun Pokok

Sebagaimana disebutkan di atas, akun pokok Laporan Pertanggungjawaban Realisasi Pelaksanaan APBDes terdiri dari pendapatan, belanja dan pembiayaan. Pendapatan desa meliputi semua penerimaan uang melalui rekening desa yang merupakan hak desa dalam satu tahun anggaran yang tidak perlu dibayar kembali oleh desa. Pendapatan desa disajikan menurut klasifikasi kelompok dan jenis pendapatan yang terdiri dari pendapatan asli daerah, transfer, pendapatan lain-lain, dan lain-lain pendapatan desa yang sah. Pendapatan asli desa dapat berupa hasil usaha, hasil aset swadaya, partisipasi dan gotong royong dan lain-lain pendapatan asli desa. Transfer terdiri dari :

a) Dana desa

b) Bagian dari hasil pajak daerah kabupaten/kota dan retribusi daerah

c) Alokasi dana desa

d) Bantuan keuangan dari APBD provinsi dan kabupaten/kota. Pendapatan lain-lain dapat berupa hibah dan sumbangan dari pihak ketiga yang tidak mengikat.

Belanja desa meliputi semua pengeluaran dari rekening desa yang merupakan kewajiban desa dalam satu tahun anggaran yang tidak akan diperoleh pembayarannya kembali oleh desa, dipergunakan dalam rangka mendanai penyelenggaraan kewenangan desa. Belanja desa disajikan berdasarkan kelompok bidang, kegiatan dan jenis belanja (klasifikasi ekonomi). Klasifikasi kelompok terbagi menjadi lima meliputi:

a) Penyelengaraan pemerintah desa

b) Pelaksanaan pembangunan desa

c) Pembinaan kemasyarakatan desa

d) Pemberdayaan masyarakat desa

e) Belanja tak terduga

Selanjutnya, klasifikasi kelompok dibagi lagi menjadi kegiatan-kegiatan dimana didalamnya terdiri dari belanja menurut klasifikasi ekonomi (belanja pegawai, belanja barang dan jasa dan belanja modal)

Pembiayaan desa meliputi semua penerimaan yang perlu dibayar kembali dan/atau pengeluaran yang akan diterima kembali, baik pada tahun anggaran yang bersangkutan maupun pada tahun anggaran berikutnya. Pembiayaan desa diakui pada saat kas diterima/dikeluarkan dan didukung dengan bukti yang lengkap dan sah. Pembiayaan disajikan berdasarkan kelompok penerimaan dan pengeluaran pembiayaan.

Selanjutnya Laporan Kekayaan Milik Desa terdiri dari tiga akun pokok yaitu aset desa, kewajiban, dan kekayaan bersih. Aset desa adalah barang milik desa yang berasal dari kekayaan asli desa, dibeli atau diperoleh atas beban APBDesa atau perolehan hak lainnya yang sah. Aset disajikan berdasarkan tingkat likuiditasnya yaitu berupa aset lancer dan aset tidak lancar. Contoh aset lancar adalah kas, piutang desa, dan persediaan. Sedangkat aset tidak lancar meliputi penyertaan modal pemerintah desa dan aset tetap milik desa (tanah, peralatan dan mesin, gedung dan bangunan, jalan, jaringan, dan instlasi), dana cadangan dan aset non lancar lainnya. Kewajiban adalah utang yang timbul karena adanya pinjaman oleh pemerintah desa. Kekayaan bersih, yaitu selisih antara aset dan kewajiban pemerintah desa. 


\section{c. Perlakuan Dana Terikat}

Pemerinntah desa memperoleh alokaasi dana dari pemerintah pusat yang dinamakan dana desa. Dalam perspektif akuntansi, dana desa tersebut merupakan salah satu bentuk pendappatan desa yang bersifat mengikat. Hal ini terlihat dari pembatasan penggunaan dana desa pada bidang tertentu sesuai prioritas yang ditetapkan, Pembangunan Daerah Tertinggal, dan Transmigrasi. Pembatasan tersebut dipertegas lagi, yaitu dengan adanya mekanisme persetujuan Bupati/Walikotaterhadap pengguanaan dana untuk hal yang tidak sesuai dengan prioritas (Peraturan Menteri Keuangan 93/PMK 07/2015, Pasal 23). Selain pembatasan penggunaan, pelaaporan dana desa juga diminta secara khusus/tersendiri. Kepala desa diminta membuat laporann realisasi penggunaan dana desa secara semesteran (pasal 25) dan dikonsilidasi di level kabupaten/kota untuk kemudian dasampaikan setiah tahun ke Menteri Keuangan c.q. Direktur Jenderal Perimbangan Keuangan dengan tembusan kepada Menteri Dalam Negeri, Menteri Desa, Pembangunan Daerah Tertinggal dan Transmigrasi, dan Gubernur (Pasal 20). Dana terikat semacam dana desa ini juga bisa muncul dari bantuan keuangan yang berasal dari APBD Provinsi dan kabupaten/kota, apabila provinsi atau kabupaten/kota menyalurkan bantuan dengan batasan-batasan penggunaan tertentu. Dengan demikian, ada kemungkinan desa mengelola beberapa maca dana terikat. Jika memang diperlukan pentingnya pengendalian terpisah atas dana terikat yang dikelola oleh desa maka ini membuka peluang penerapan akuntansi dana pada pemerintah desa, sebagaimana Sap juga membuka peluang tersebut dalam Kerangka Konseptual paragraf 15. Namun demikian, penerapan praktik ini perlu mempertimbangkat kesiapan sumber daya manusiaa pada pemerintah desa. Banyaknya produk laporan juga berisiko mengganggu kinerja aparat desa dalam memberikan pelayanan kepada masyarakat.

Akuntabilitas adalah kewajiban pemegang amanah/agent/kepala desa dan aparatnya untuk memberikan pertanggungjawaban, menyajikan, melaporkan, dan mengungkapkan segala aktivitas dan kegiatan yang menjadi tanggung jawabnya kepada pihak yang pemberi amanah (principal) yang memiliki hak dan kewenangan untuk meminta pertanggungjawaban tersebut. Secara singkat, kepala desa dan aparaturnya harus mempertanggjungjawabkan pengelolaan sumber daya serta pelaksanaan kebijakan yang dipercayakan kepada entitas pelaporan dalam mencapai tujuan yang telah ditetapkan secara periodik. Transparasi memberikan informasi keuangan yang terbuka dan jujur kepada masyarakat berdasarkan pertimbangan bahwa masyarakat memiliki hak untuk mengetahui secara terbuka dan menyeluruh atas pertanggungjawaban pemerintah dalam mengelola sumber daya yang dipercayakan kepadanya dan ketaatannya pada peraturan perundang-undangan.

Hal lain yang mempengaruhi kualitas laporan keuangan sektor publik adalah kualitas sumber daya manusia. Dengan kata lain, rendahnya pemahaman tentang akuntansi berpengaruh terhadap pembuatan laporan keuangan serta transparasi dan akuntabilitas pengelolaan keuangan daerah. Kualitas laporan keuangan sektor publk di Indonesia masih mengalami berbagai kendala. Belum baiknya sistem akuntansi yang diterapkan dan rendahnya pemahaman terhadap akuntansi merupakan beberapa kendala yang dihadapi sektor publik di Indonesia. Masalah tersebut terjadi baik di level pemerintah pusat maupun pemerintah daerah.

Sistem akuntansi yang diterapkan di Desa pacung yaitu sistem akuntansi berbasis kas menuju akrual yaitu pengakuan basis kas untuk pengakuan pendapatan, belanja, dan pembiayaan dalam Laporan Realisasi Anggaran dan basis akrual untuk pengakuan aset, kewajiban, dan ekuitas.

Dari hasil wawancara dan observassi yang telah dilakukan diperoleh beberapa temuan bahwa permasalahan administrasi pada tahun 2015 terjadi akibat keterbatasan pemahaman tentang akuntansi dalam proses pencatatan transaksi-transaksi yang terjadi. Kepala desa menyadari bahwa pengukuran dana desa yang bersumber dari APBDesa ini menuntut pertanggungjawaban dari setiap pemakaian rupiahnya. Permendagri No.113 mengatur secara detail proses pelaporannya. Dalam permendagri ini diatur nomor rekening, proses pencatatan dan format dana desa. Di sisi lain para kepala desa dan 
aparatnya belum memiliki pemahaman yang memadai terhadap peraturan tersebut. Mereka mengeluhkan detailya pencatatan dan pelaporan dana desa ini. Hal tersebut juga berpengaruh dengan minimnya sumber daya manusia pada level desa. Hampir sebagian besar aparat di level desa sudah berusia tua, dan hanya sedikit pegawai desa yang berusia muda dan memungkinkan bisa diminta mempelajari Permendagri tersebut.

Dari wawancara tersebut didapat permasalahan terkait dengan implementasi dana desa seperti permasalahan yang terjadi di tahun 2015, dimana terjadi kesalahan pencatatan dan administrasi organisasi, serta pembayaran pajak. Pemerintah Desa Pacung menyadari hal ini terjadi karena kurangnya kompetensi dari pegawai desa khususnya di bidang akuntansi.

Permasalahan pencatatan yang terjadi diantaranya, penganggaran dalam APBDesa untuk lomba HKG yang tidak dicatat secara terperinci. Dimana disana hanya mencatat biaya untuk lomba HKG sehingga tidak ada transparansi, sehingga ketika dilakukan pembelian seragam untuk keperluan lomba koor (PKK), pengeluaran ini dianggap sebagai penyalahgunaan anggaran. Permasalahan lainnya adalah pembayaran pajak. Ketika melakukan pembangunan terjadi banyak sekali pembelian, namun ketika hendak membayar pajak pegawai kurang memahami bagaimana cara membayar pajak dengan SPT.

\subsection{Pengelolaan Keuangan Desa dan Sistem Akuntansi yang Diterapkan dapat Meningkatkan Kinerja Desa Pacung}

Berdasarkan pembahasan permasalahan pengelolaan keuangan Pemerintah Desa Pacung dan permasalahan Sistem Akuntansi Desa Pacung, akan membuat kinerjaa pemerintah desa menjadi lebih baik. Dengan adanya pengelolaan keuangan Desa pacung dapat meningkatkan kinerja suatu pemerintah desa itu sendiri dengan melaksanakan kegiatan sesuai dengan tugas dan fungsinya secara efektif dan efesien. Sehingga dengan adanya pengelolaan keuangan desa dapat mendorong terwujudnya kinerja pemerintah desa yang lebih berkualitas, bebas dari praktik korupsi, kolusi, dan nepotisme. Begitu juga dengan dengan sistem akuntansi keuangan desa. Sistem Akutansi Keuangan Desa Pacung memiliki arti yang sangat penting dalam rangka pelaksanaan pemerintahan, oleh karena itu sistema akutansi keuangan desa diupayakan untuk terus berjalan meningkatkan kinerja pemerintah Desa Pacung.

Kinerja pemerintahan organisasi Pemerintah Desa pacung tergolong baik, hal ini dapat dilihat dari kepuasan masyarakat Desa Pacung dalam pengadaan air bersih. Dengan dibangunnya penampungan air di Desa Pacung maka masyarakat di Desa pacung tidak lagi kekurangan air bersih. Tidak hanya itu, air tersebut juga digunakan dibidang pertaniaan sehingga dapat meningkatkan perekonomian masyarakat Desa Pacung.

\section{Simpulan dan Saran}

Kesimpulan yang dapat diambil dari Pengelolaan Keuangan Desa dan Sistem Akuntansi Keuangan terhadap Kinerja Organisasi Pemerintah pada Pemerintah Desa Pacung adalah sebagai berikut:

1) Pengelolaan keuangan desa yang baik dapat meningkatkan kinerja organisasi pemerintah desa.

2) Sistem akuntansi keuangan desa yang baik dapat meningkatkan kinerja organisasi pemerintah di Desa Pacung.

Berdasarkan hasil penelitian yang telah dilakukan, ada beberapa saran yang dapat dipertimbangkan oleh beberapa pihak:

1) Instansi agar saat paada aturan atau prosesdur dalam melakukan kegiatan, serta mengusahakan ketepatan waktu dalam menghasilkan barang dan jasa.

2) Instansi agar lebih sering melakukan evaluasi kinerja yang terkait dengan pengelolaan keuangan.

3) Dalam melakukan penjurnalan dan postingan sebaiknya dilakukan sesuai dengan nomor yang telah ditetapkan pemerintah. 


\section{DAFTAR PUSTAKA}

Brodjonegoro, B. P. S. 2014. Pemerintah Tambah Alokasi Dana Desa dalam APBN-P 2015. Available at http://www.kemenkeu.go.id

Faozi, C. 2015. Undang-undang desa, apakah mimpi buruk bagi aparatur pemerintah desa?. Available at http://www.kompasiana.com.

Faozi, C. 2015. Harap-harap cemas undang-undang desa. Available at http://www.kompasiana.com.

Gustiawan. 2013. Pengolahan data kependudukan: Menghasilkan laporan data penduduk, masuk, meninggal, lahir, pindah dan laporan umur. Available at $h$ ttp://katadata.co.id.

Peraturan Menteri Dalam Negeri Republik Indonesia Nomor 113 Tahun 2014 tentang Pengelolaan keuangan desa.

Peraturan Pemerintah Republik Indonesia Nomor 24 Tahun 2005 tentang Standar akuntansi pemerintahan.

Peraturan Pemerintah Republik Indonesia Nomor 43 Tahun 2014 tentang Peraturan pelaksanaan Undang-Undang Nomor 6 tahun 2014.

Peraturan Pemerintah Republik Indonesia Nomor 60 Tahun 2014 tentang Dana desa yang bersumber dari Anggaran Pendapatan dan Belanja Negara.

Peraturan Pemerintah Republik Indonesia Nomor 71 Tahun 2010 tentang Standar akuntansi pemerintahan. 